\title{
PENERAPAN IDENTITAS LOKAL PADA MEBEL KAYU MELALUI PELATIHAN DAN PENDAMPINGAN
}

\author{
Irfan, Ali Ahmad Muhdy, Hamrin \\ Fakultas Seni dan Desain Universitas Negeri Makassar \\ irfanridh@unm.ac.id \\ ali.ahmad.muhdy@unm.ac.id \\ hamrin@unm.ac.id
}

\begin{abstract}
Abstrak
Kelurahan Mannongkoki di kabupaten Takalar merupakan sentra industri mebel kayu lokal, namun kebanyakan produk mebel yang dibuat adalah mebel tradisional tanpa ukiran.Terdapat ratusan kelompok usaha mebel kayu, namun hanya dua unit usaha yang dapat membuat mebel ukir, oleh sebab itu kedua unit usaha mebel tersebut kesulitan dalam memenuhi perminataan pembeli terhadap mebel ukir. Permasalahannya adalah kekurangan tenaga utama pengukir kayu, sehingga jumlah produk yang dihasilkan sangat terbatas dan belum mampu memenuhi permintaan pembeli. Permasalahan lainnya adalah mebel ukir yang dibuat terkadang tidak sesuai dengan keinginan pembeli, sebab pembeli menginginkan mebel dengan ukiran baru. Oleh sebab itu, upaya pembinaan dan pelatihan mengukir untuk menambah tenaga pengukir yang dimiliki perlu dilakukan. Selain itu, perlu menawarkan ukiran baru bernuanasa lokal, agar mebel ukir yang dibuat dapat menarik minat pembeli dan sekaligus menampilkan identitas lokal dengan ukiran baru yang dikembangkan dari ikon budaya lokal khususnya di Kabupeten Takalar. Melalui PKM Perajin Mebel Mannongkoki dilakukan pelatihan dan pendampingan agar dapat menambah tenaga pengukir. Hasil PKM menunjukkan bahwa pada umumnya pemuda lokal dapat dilatih membuat dan mengeksplorasi ornament sesuai kreativitasnya, bahkan dapat menerapkan sebagai ukiran pada kayu, namun masih perlu kesungguhan dan komitmen agar dapat menekuni pekerjaan sebagai pengukir. Hasil PKM juga telah menambah tenaga pengukir menjadi 4 orang dan telah menerapkan ornament lokal sebagai salah satu alternatif produk yang dijual.
\end{abstract}

Kata Kunci: Mebel Kayu, Ukiran, Lokal

\section{PENDAHULUAN}

Kabupaten Takalar memiliki banyak sentra usaha kecil kerajinan mebel dari bahan kayu yang belum pernah mengalami pembinaan maupun upaya pengembangan produk. Kebanyakan perajin mebel kayu tradisional tersebut mengelola usahanya dengan sistem home industri, bekerja dikolong-kolong rumah masing-masing dan dibantu oleh beberapa orang tukang tambahan untuk memenuhi pesanan toko- toko mebel di daerah sekitarnya (lokal). Kebanyakan produk mebel kayu buatan perajin lokal tersebut hanya untuk memenuhi pesanan konsumen lokal dengan kelas ekonomi menengah kebawah, sebab harganya yang relatif lebih terjangkau dibanding produk mebel kayu dari luar daerah dengan ukiran yang rumit dan bahan kayu yang lebih berkualitas. Di antara puluhan kelompok usaha pembuat mebel kayu, hanya dua unit usaha yang khusus membuat mebel ukiran, itupun hanya membuat bentuk dan ukiran tiruan dari mebel luar daerah, kebanyakan ukiran yang ditiru dari Jepara. Kedua kelompok usaha mebel ukir kayu yang menjadi mitra adalah Sutarmanto dan Yani. Sutarmanto memiliki usaha yang diberi nama "METOMO 02".

Sutarmanto telah memulai usahanya sejak tahun 1998 di Mannongkoki Kabupaten Takalar, usaha ini dirintis sebab adanya permintaan akan mebel ukir oleh konsumen lokal di Takalar maupun Kabupaten lainnya, selama puluhan tahun menekuni pembuatan usaha mebel ukir Sutarmanto dibantu oleh 5 karyawan, satu pengukir, dua tukang rakit dan dua tenaga finishing lemari. Setiap bulan puluhan lemari ukir bisa dibuat dari berbagai pesanan, namun bentuk mebelnya masih 
imajinaasi

monoton, tingkat produktifitas untuk lemari ukiran masih rendah serta belum mengalami kemajuan yang berarti. Dari aspek pemsaran, pada umumnya Metamo 02 masih mengandalkan sistem pemasaran lama melalui jaringan dan langganan serta menjual langsung di Toko sekaligus tempatnya bekerja, beberapa tahun terakhir, pemilik Metamo 02, Bapak Sutarmanto membuat Facebook untuk memasarkan produknya, namun masih kurangnya pertemanan dan pengetahuan tentang pemasaran online sehingga pemasaran secara online msih belum maksimal. Di sisi lain, banyaknya pesanan mebel ukir membuat metamo kurang inisiatif untuk mengembangkan usahanya lebih maju dan lebih produktif.

Pada musim menjelang lebaran Idul Fitri permintaan mebel ukir terkadang menumpuk, misalnya pesanan ada 40 buah, namun yang sanggup dikerjakan hanya 15 buah. Salah satu permasalahan utama yang dihadapi adalah kurangnya perajin ukiran sebab setiap pesanan lemari ukiran hanya dikerjakan oleh satu tukang ukir, terkadang Sutarmanto sebagai pemilik usaha juga ikut membantu mengukir lemari pesanan untuk mencapai target. Hal tersebut disebabkan sulit untuk mendapatkan tenaga ukir yang handal terlatih, untuk melatih orang baru agar bisa mengukir membutuhkan waktu tersendiri dan membutuhkan pihak lain sebagai pendamping. Keterampilan mengukir pada umumnya dapat diperoleh melalui latihan dan pembiasaan, jika calon pengukir tekun belajar dan latihan mengukir, maka dalam waktu 2 bulan para calon pengukir dapat mengukir sendiri dengan level keterampilan mengukir dasar. Ukiran merupakan salah satu daya tarik dari mebel yang diproduksi Metammo 02.

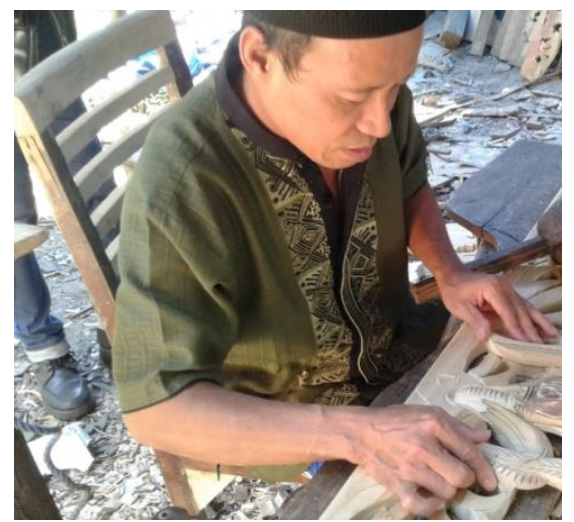

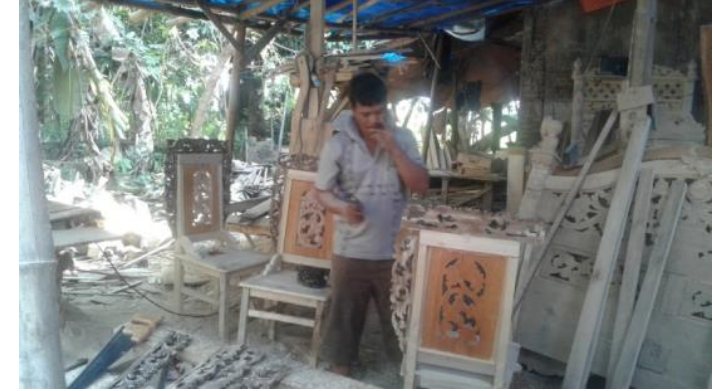

Gambar 1. Sutarmanto dan pengukirnya

Terkait dengan ukiran atau ragam hias bisa juga diistilahkan dengan ornamen mempunyai arti : a) dekorasi; b) sesuatu yang dirancang untuk menambah keindahan benda, tetapi biasanya tanpa kegunaan praktis; c) tindakan, kualitas yang menambah keindahan. Ornamen disamakan dengan dekorasi, atau kegiatan untuk menghias benda agar menambah keindahannya. Istilah dekorasi berarti seni atau proses penerapan beragam elemen guna memperindah objek. Dekorasi adalah upaya untuk memberikan elemenelemen tambahan guna memperindah, elemen tambahan tersebut dapat berupa warna, motif, anyaman, atau penambahan tekstur tertentu. Jenis ornamen dapat diklasifikasikan ke dalam ornamen organis dan ornamen inorganis. Ornamen organis adalah ornamen yang bersumber pada fenomena alam yang hidup (hayati), ornamen organis merupakan jenis ornamen yang dalam tampilannya menggunakan elemen-elemen atau organorgan hayati, baik yang berasal dari tanaman, binatang, maupun manusia. Misalnya dari akar, batang, ranting, daun, bunga dan buah (contoh dari tanamandan ornamen inorganis adalah ornamen yang bersumber pada fenomena alam yang tidak hidup, ornamen inorganis merupakan suatu perwujudan ornamen yang bersumber dari berbagai fenomena alam yang tidak hidup. Ornamen ini tampak seperti awan, bintang, bulan, matahari, sungai, karang, dan lain-lain [1]. Ornamen pada mebel ukir dari Metamo 02 kebanyakan ornamen organis, namun masih merupakan peniruan dari ornament luar, oleh sebab itu penting memunculkan ornament organis baru yang digali dari nilai lokal yang ada di Kabupaten Takalar.

Mitra "Metamo 02" mebel telah memiliki satu pengukir handal, bahkan 
pemilik usaha Bapak Sutarmanto juga terampil mengukir, sehingga sudah banyak produk mebel ukir yang telah diproduksi, walaupun demikian, kapasitas prosuksi masih terbatas dan membutuhkan dukungan untuk merekrut tenaga untuk dilatih mengukir, sistem pelatihan mengukir yang disepakati dengan mitra adalah melalui kerjasama antara tim pengabdi dengan mitra, tim pengabdi akan membantu merekrut pemuda lokal lalu memfasilitasi dalam mengikuti pelatihan dan pendampingan, namun mitra sendiri memiliki kesediaan untuk menjadi instruktur dan melatih mereka untuk terampil mengukir, agar dapat menjadi tenaga pengukirnya kelak demi meningkatkan produktifitas. Di sisi lain, mitra membutuhkan desain bentuk mebel baru serta ukiran baru untuk diproduksi. Pentingnya memasukkan unsur budaya lokal pada ukiran lemari dapat memberikan identitas baru dan sekaligus estetika baru yang patut di tawarkan kepada pembeli, dengan demikian, variasi bentuk dan ukiran dapat bertambah banyak dan sekaligus memperkuat identitas visual daerah Kabupaten Takalar melalui produk mebel kayu lokal.

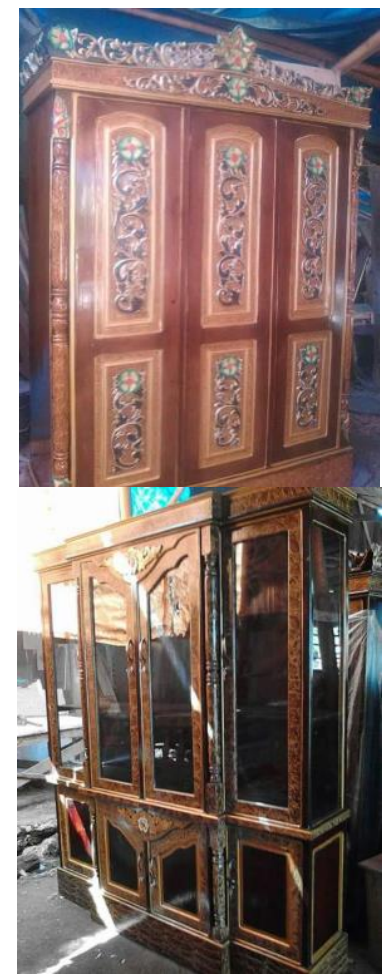

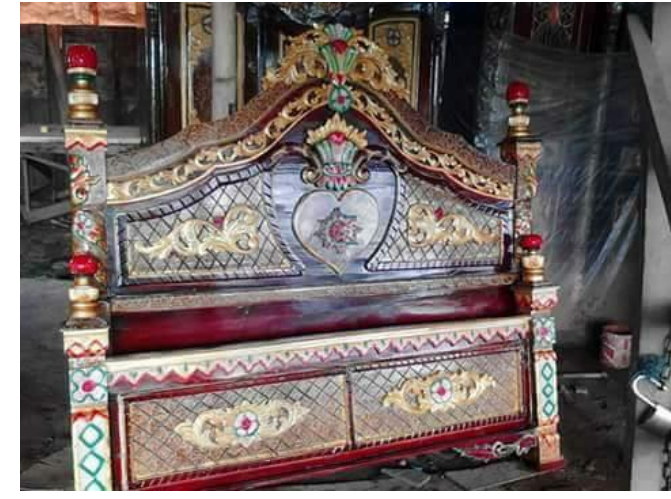

Gambar 2. Produk ukiran hasil produksi usaha "Metamo 02" milik Sutarmanto

Mebel dilihat dari aspek budaya, merujuk pendapat Koentjaraningrat, wujud kebudayaan ada tiga: 1) Wujud kebudayaan sebagai suatu kompleks dari ide-ide, gagasan, nilai-nilai, norma-norma, peraturan dan sebagainya; 2) Wujud kebudayaan sebagai suatu kompleks aktivitas kelakuan berpola dari manusia dalam masyarakat; 3) wujud kebudayaan sebagai benda-benda hasil karya manusia, ia berupa kebudayaan fisik yang berbentuk nyata dan merupakan hasil karya masyarakat [2]. Mebel dapat dikategorikan sebagai wujud kebudayaan ketiga. Pada dasarnya budaya adalah nilai-nilai yang berlaku pada suatu masyarakat. Artefak sebagai salah satu produk budaya merupakan cerminan nilai-nilai yang berlaku pada masyarakat tersebut, sehingga secara langsung akan berakibat pada sikap dan perilaku masyarakat di lingkungan tersebut. Melalui artefak, perbedaan budaya dapat terlihat seperti penggunaan sendok, garpu dan pisau, penggunaan kemudi kanan atau kiri pada mobil, bentuk-bentuk dan ukiran pada mebel kayu lokal dapat memperlihatkan adanya perbedaan antara budaya suatu daerah dengan daerah lainnya [3]. Melalui program kemitraan masyarakat ini, diharapkan mitra mendapatkan tenaga pengukir tambahan yang terampil, membuat bentuk dan desain mebel baru, serta memperoleh tambahan pengetahuan cara mengembangkan motif lokal untuk meningkatkan estetika mebel yang diproduksi. Di sisi lain, ukiran yang diterapkan dapat menjadi identitas baru bagi Kabupaten Takalar. 


\section{METODE}

Metode pendekatan yang digunakan adalah ceramah, diskusi, wawancara, pendampingan dan demonstrasi/penerapan. Sedangkan metode pengembangan ukiran sebagai hiasan menggunakan pendekatan pelibatan dan patisipasi mitra, artinya mitra tidak semata-mata ditempatkan sebagai objek atau sasaran saja akan tetapi ditempatkan sebagai mitra atau partner yang bersama-sama dengan tim pengabdi menjalankan kegiatan program. Partisipasi yang dapat dilakukan perajin dengan mengemukakan berbagai gagasan-gagasan yang dimilikinya (stilasi dan diversivikasi ukiran) dalam program kemitraan masyarakat, sehingga gagasan tersebut dapat diakomodasi. Penerapan pendekatan partisipasi ini selanjutnya akan menjadikan mitra sebagai inovator/kreator, sekaligus sebagai penjual dan pemasar bagi produk-produk yang akan dihasilkannya. Metode ini sejalan dengan pandangan Dudy Wiyancoko, desainer bertugas menyampaikan gagasan pemecahan masalah dan mengajak masyarakat berperan serta dalam mendesain, mengevaluasi penemuan sains dan teknologi agar peka terhadap inovasi melalui pelatihan, pemanduan, pencatatan, publikasi dan penghargaan [5].

Metode Ceramah untuk melakukan sosialisasi dan menjelaskan kepada mitra dan calon pengukir tentang kegiatan PKM, persiapan, peraturan, syarat, serta rencana pelaksanaan kegiatan, dan rencana keberlanjutan kegiatan setelah program selesai.

Metode wawancara akan digunakan untuk menggali dan mengidentifikasi motivasi calon pengukir untuk belajar mengukir dalam bidang seni ukir kayu, wawancara juga akan diguanakan untuk mengidentifikasi kesiapan mitra dan prospek pengembangan ukiran serta pemasaran produk mebelnya.

Metode Demonstrasi dan penerapan digunakan untuk melatih mitra memproduksi desain bentuk lemari baru, demikian pula calon pengukir agar terampil membuat dan menerapkan ukiran baru. Selain itu, perlu pula penerapan ukiran didemostrasikan, mulai pembuatan sketsa, lalu penempelan pada panel kayu, lalu teknik ukiran dengan pahat.
Metode demonstrasi juga digunakan untuk proses stilasi dan revitalisasi ukiran.

Metode pendampingan digunakan dalam rangka melakukan evaluasi atas hasil pelatihan, mengontrol dan mmemberikan bimbingan kepada mitra, baik pengembangan desain, pengembangan ukiran dan peningkatan produktifitas, bahkan mendampingi dalam hal pemasaran produk hasil pelatihan. Pendampingan dilakukan untuk menjaga keberlanjutan program agar keterampilan yang telah diberikan dapat bermanfaat bagi dirinya, dan masyarakat secara umum.

\section{HASIL DAN PEMBAHASAN}

Sebelum melaksanakan kegiatan pelatihan mengukir, langkah awal yang dilakukan adalah kembali bertemu mitra untuk mendiskusikan kembali rencana program yang disepakati. Dari hasil pertemuan diputuskan untuk melaksanakan pelatihan membuat dan mengeksplorasi motif dan pelatihan menerapkan motif pada bahan kayu yang telah disiapkan. Untuk penerapan motif lokal pada mebel jadi, mitra belum berani melibatkan anggota mitra yang baru belajar, namun akan dibuat oleh pengukir yang mahir melalui proses pendampingan. Pada tahap observasi dan sosialisasi ini juga dilakukan seleksi calon peserta pelatihan, sesuai kesepakatan dan hasil diskusi dengan mitra bahwa peserta pelatihan dibatasi jumlahnya maksimal 10 orang dengan materi membuat motif lokal dan menerapkan pada bahan kayu. Setelah itu dilanjutkan dengan kegiatan pendampingan, dimana mitra menerapkan ornament lokal pada salah satu produk mebel kayunya.

\subsection{Pelatihan Membuat dan Menerapkan Ornamen Lokal}

Kegiatan pelatihan dilakukan selama dua hari yang diikuti oleh 10 orang peserta dari pemuda yang tinggal di sekitar lokasi mitra. Pada tahap awal masing-masing peserta diberikan contoh ornament yang dikembangkan dari jagung sebagai komoditas lokal Kabupaten Takalar, setelah itu peserta diberi kesempatan untuk mengembangkan sendiri ornament sesuai kreasinya. 


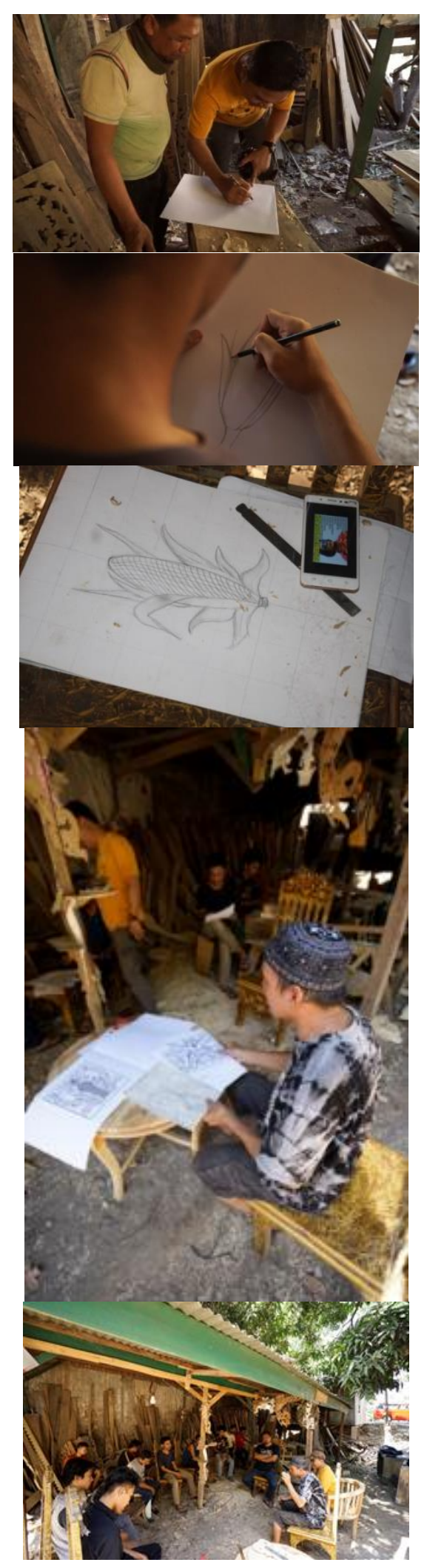

Gambar 3. Instruktur membimbing untuk berkreasi dan menggambar
Secara umum hasil pelatihan diuraikan dalam tabel dengan kategori rentang nilai $10-100$. Nilai 10 - 60 kurang, 60 - 79 cukup, 80 - 89 bagus, dan $90-100$ sangat bagus. Penentuan skor dilakukan dengan mempertimbangkan indikator pada setiap aspek yang dinilai, misalnya untuk aspek pembuatan dan eksplorasi ornament akan dinilai kreativitas, estetika, dan penyelesaian gambar (finishing). Sedangkan pada aspek penerapan ornament akan dinilai adalah teknik mengukir, durasi waktu, dan hasil.

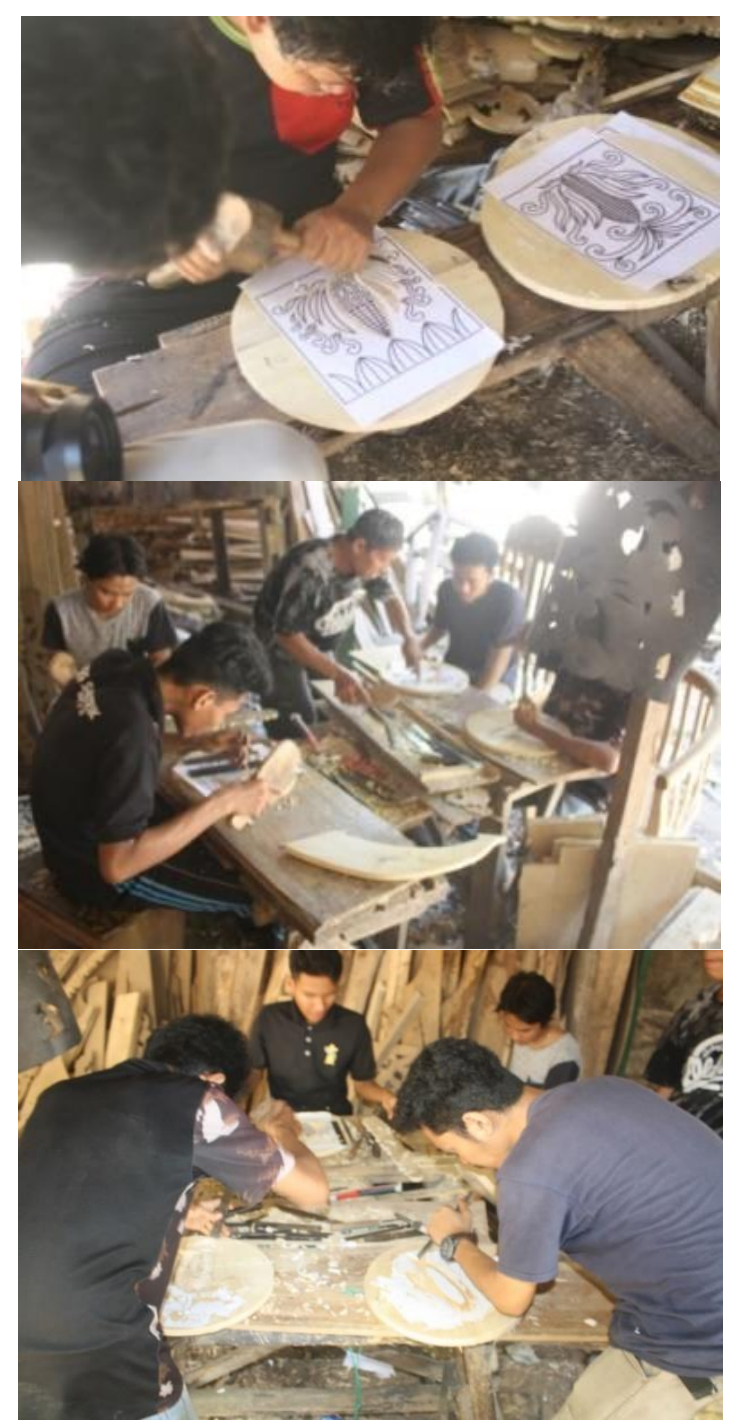

Gambar 4. Menerapkan ornament yang telah ditempel pada bahan kayu 
T;abel Hasil Pelatihan Eksplorasi Jagung sebagai ornamen Lokal

\begin{tabular}{|c|c|c|c|c|}
\hline No & Nama & 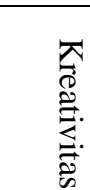 & $\begin{array}{l}\frac{(T)}{2} \\
\overrightarrow{0} \\
\stackrel{\vec{D}}{\vec{D}}\end{array}$ & : \\
\hline 1 & $\begin{array}{l}\text { Wahyudi } \\
\text { Bora }\end{array}$ & 85 & 87 & 92 \\
\hline 2 & $\begin{array}{l}\text { Muh. Yusuf } \\
\text { Ashenri }\end{array}$ & 97 & 92 & 99 \\
\hline 3 & $\begin{array}{l}\text { Edi } \\
\text { Siswanto }\end{array}$ & 75 & 77 & 70 \\
\hline 4 & Eko & 84 & 90 & 92 \\
\hline 5 & Firman & 98 & 95 & 96 \\
\hline 6 & Viqi & 85 & 87 & 55 \\
\hline 7 & Rizal & 75 & 77 & 65 \\
\hline 8 & $\begin{array}{l}\text { Ahmad } \\
\text { Noor } \\
\text { Diyansyah } \\
\end{array}$ & 75 & 70 & 50 \\
\hline 9 & $\begin{array}{l}\text { Alex Dg } \\
\text { Sewang }\end{array}$ & 75 & 70 & 70 \\
\hline 10 & Daeng Mone & 75 & 70 & 70 \\
\hline \multicolumn{2}{|c|}{ Nilai Rata-rata } & 82,4 & 82 & 76 \\
\hline
\end{tabular}

Hasil pelatihan terhadap 10 orang calon pengukir dari kelompok mitra menunjukkan bawa kreativitas sudah bagus dengan nilai rata-rata 82,4, demikian juga estetika berada pada kategori bagus dengan nilai rata-rata 82 , namun masih rendah pada tahap penyelesaian gambar sebab nilai ratarata hanya 76 atau kategori cukup. Pada umumnya calon peserta sudah bisa menggambar dan mengeksplorasi sendiri ornament dengan melihat contoh lalu dikembangkan, namun masih lemah dalam penyelesaian. Dari nilai aspek finishing hanya 4 orang peserta yang menyelesaikan gambar hingga tuntas, bahkan diterapkan pada ukiran kayu, sedangkan 6 peserta lainnya tidak menuntaskan gambarnya, namun tetap digunakan sebagai acuan untuk mengukir ornament pada kayu.

Tabel hasil penerapan ornament pada bahan kayu sebagai ukiran

\begin{tabular}{|l|l|c|c|c|}
\hline No & Nama & Teknik & Waktu & Hasil \\
\hline 1 & $\begin{array}{l}\text { Wahyudi } \\
\text { Bora }\end{array}$ & 75 & 87 & 82 \\
\hline 2 & Muh. & 88 & 92 & 85 \\
\hline
\end{tabular}

\begin{tabular}{|l|l|c|c|c|}
\hline & $\begin{array}{l}\text { Yusuf } \\
\text { Ashenri }\end{array}$ & & & \\
\hline 3 & $\begin{array}{l}\text { Edi } \\
\text { Siswanto }\end{array}$ & 95 & 92 & 99 \\
\hline 4 & Eko & 87 & 90 & 70 \\
\hline 5 & Firman & 88 & 95 & 85 \\
\hline 6 & Viqi & 85 & 87 & 65 \\
\hline 7 & Rizal & 75 & 57 & 65 \\
\hline 8 & $\begin{array}{l}\text { Ahmad } \\
\text { Noor } \\
\text { Diyansyah }\end{array}$ & 75 & 57 & 50 \\
\hline 9 & $\begin{array}{l}\text { Alex Dg } \\
\text { Sewang }\end{array}$ & 75 & 60 & 70 \\
\hline 10 & $\begin{array}{l}\text { Daeng } \\
\text { Mone }\end{array}$ & 75 & 65 & 70 \\
\hline Nilai Rata-rata & 82 & 78 & 74 \\
\hline \multicolumn{4}{|l}{} \\
\hline
\end{tabular}

Hasil penerapan ornament pada papan kayu dengan teknik ukir menunjukkan bahwa nilai rata-rata teknik ukir 82 berada pada kategori bagus, waktu penyelesaian karya rata-rata 78 kategori cukup dan penyelesaian hasil rata-rata 74 atau kategori cukup. Pada item teknik ukir hanya 1 peserta yang dapat 95 sangat bagus yaitu edi siswanto sebab merupakan pengukir baru dari mitra, 4 peserta kategori bagus dan sisanya lima orang berada pada kategori cukup. 9 peserta merupakan orang baru yang direkrut untuk dilatih mengukir agar dapat menjadi tenaga tambahan bagi mitra. Dari ketiga indikator penilaian aspek penerapan ornament, belum ada yang mencapai kategori sangat bagus, indicator teknik ukir berada pada kategori bagus, dan dua indikator lainnya, waktu dan hasil berada pada kategori cukup. Hal tersebut menunjukkan bahwa masih perlu latihan bagi para peserta dengan bekerja di bawah bimbingan dan sekaligus membantu mitra.

\subsection{Pendampingan dan Evaluasi}

Setelah kegiatan pelatihan dilanjutkan dengan kegiatan pendampingan pada mitra, focus pendampingan adalah bagimana mitra dapat menerapkan ornament lokal yang telah dieksplorasi sebelumnya yaitu jagung dan ikan terbang. Selain itu, pendampingan juga dilakukan pada aspek pemasaran dengan memanfaatkan media social sebagai salah satu medi promosi. Media sosial online yang digunakan adalah instagram. 


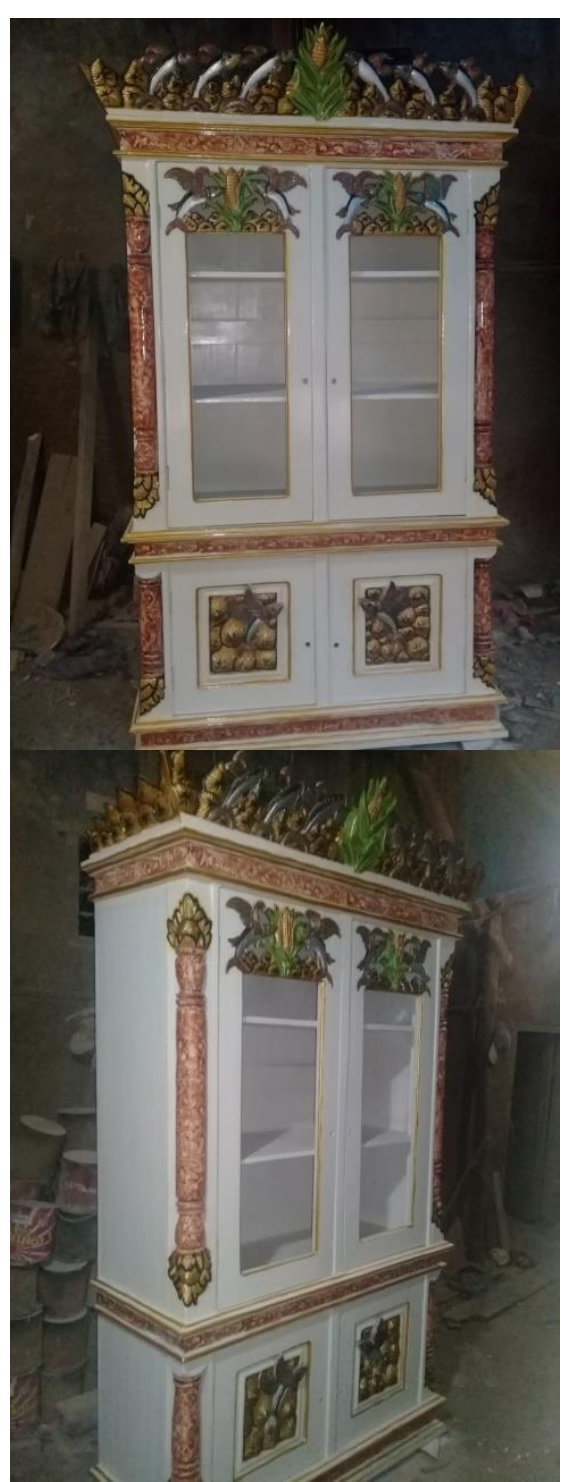

Gambar 5. Lemari kaca dengan ornament lokal yang dikembangkan dari ikan terbang dan jagung sebagai komoditas dan identitas Kabupaten Takalar

Pendampingan dilakukan mulai dari tahap desain/rancangan mebel, jenis ukiran yang akan diterapkan, teknik ukir hingga proses finishing. Jenis mebel yang dibuat adalah lemari kaca dari bahan kayu jati putih sehingga memudahkan untuk diukir, lemari kaca ini dapat dugunakan sebagai lemari tempat penyimpanan ibu rumah tangga dan dapat pula sebagai tempat buku, oleh sebab itu rak-rak lemari dibuat lebih tebal dari biasanya. Dari hasil pendampingan terhadap penerapan ornament lokal pada produk mebel kayu yang siap jual menunjukkan bahwa lemari dibuat dengan warna putih dan ornament warna emas yang dipadukan dengan warna hijau dan perak. Teknik finishing yang dipilih adalah teknik semprot dengan menggunakan mesin kompressor menggunakan bahan cat avian dipadukan cat diko. Biaya produksi lemari adalah Rp. 2.500.000 dengan margin keuntungan 20\% maka dapat dijual seharga Rp. 3.000.000.

\section{KESIMPULAN DAN SARAN 4.1. Kesimpulan}

Pada umumnya calon peserta sudah bisa menggambar dan mengeksplorasi sendiri ornament dengan melihat contoh lalu dikembangkan, namun masih lemah dalam penyelesaian. Dari nilai aspek finishing hanya 4 orang peserta yang menyelesaikan gambar hingga tuntas, bahkan diterapkan pada ukiran kayu, sedangkan 6 peserta lainnya tidak menuntaskan gambarnya, namun tetap digunakan sebagai acuan untuk mengukir ornament pada kayu.

Pada aspek teknik ukir hanya 1 peserta yang dapat 95 sangat bagus yaitu edi siswanto sebab merupakan pengukir baru dari mitra, 4 peserta kategori bagus dan sisanya lima orang berada pada kategori cukup. 9 peserta merupakan orang baru yang direkrut untuk dilatih mengukir agar dapat menjadi tenaga tambahan bagi mitra. Dari ketiga indicator penilaian aspek penerapan ornament, belum ada yang mencapai kategori sangat bagus, indicator teknik ukir berada pada kategori bagus, dan dua indicator lainnya, waktu dan hasil berada pada kategori cukup. Hal tersebut menunjukkan bahwa masih perlu latihan bagi para peserta dengan bekerja di bawah bimbingan dan sekaligus membantu mitra.

\subsection{Saran}

Perlu program pembinaan dan pengembangan yang lebih besar agar dapat melibatkan lebih banyak komunitas pembuat mebel yang ada di Mannongkoki kabupaten Takalar Sulawesi Selatan. 


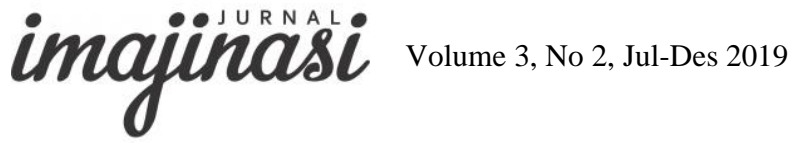

\section{UCAPAN TERIMA KASIH}

Terima kasih kepada Direktorat Riset dan Pengabdian Masyarakat Direktorat Jenderal Riset dan Pengembangan Ristek Dikti atas program PKM, terima kasih kepada Rektor Universitas Negeri Makassar, Ketua LPPM UNM, Dekan FSD UNM, Ketua Jurusan Seni Rupa dan Desain FSD UNM, mitra usaha (Sutarmanto) serta seluruh Tim PKM.

\section{DAFTAR PUSTAKA}

Guntur, 2004, Ornamen Sebuah Pengantar, Surakarta: P2AI STSI Surakarta bekerjasama dengan STSI Press Surakarta.

Koentjaraningrat, 1993, Masalah Kesukubangsaan dan Integrasi Nasional, Jakarta: UI Press.

Masri, Andry, 2010, Strategi Visual Bermain Dengan Formalistik dan Semiotik Untuk Menghasilkan Kualitas Visual Dalam Desain, Yogyakarta: Jalasutra, 2010.

Irfan dan Saleh Husain, 2017, Penerapan Ukiran Lokal Pada Mebel Kayu Guna Meningkatkan Nilai Tambah Usaha Mebel di Kabupaten Takalar Sulawesi Selatan, Prosiding Seminar Nasional "Membangun Indonesia Melalui Hasil Riset" Lembaga Penelitian Universitas Negeri Makassar, 126-130.

Wiyancoko, Duddy, 2000, "Dimensi Kebudayaan Dalam Desain", Orasi Ilmiah pada Penerimaan Mahasiswa Baru Institut Teknologi Bandung, 18 Agustus 2000 di Sasana Budaya Ganesa,Bandung 